\title{
Analysis and Discussion on the Tax Issues of Perpetual Bonds
}

\author{
Hangying Shan \\ Department of Accounting, Tongji Zhejiang College, Jiaxing, China \\ Email address: \\ 44835190@qq.com
}

\section{To cite this article:}

Hangying Shan. Analysis and Discussion on the Tax Issues of Perpetual Bonds. Journal of Finance and Accounting. Vol. 7, No. 2, 2019, pp. 56-59. doi: 10.11648/j.jfa.20190702.14

Received: April 12, 2019; Accepted: May 20, 2019; Published: May 23, 2019

\begin{abstract}
From the perspective of issuers and investors, this paper analyzes the issue of corporate income tax and turnover tax related to perpetual bonds. From the perspective of tax planning, the tax-saving effect of perpetual bonds recognized as liabilities is considerable. However, there are duplicate tax issues for investors' income. In order to eliminate the problem of double taxation, this paper proposes that the investor's perpetual debt income should be treated as tax-free income. From the perspective of turnover tax, investors should pay VAT regardless of whether they can issue special VAT invoices. However, the issue fee and underwriting income of the issuer's interest expenses and financing are not deductible.
\end{abstract}

Keywords: Perpetual Bonds, Issuer, Investor, Income Tax, Turnover Tax

\section{Introduction}

Perpetual debt refers to a bond that has no maturity date. The holder cannot ask for the payment of the capital, but the interest can be paid on time. It has also become a "stock in bonds", and it is a type of hybrid financing instrument. The issuer generally has the option to renew, an option to adjust the issuer's interest rate and others, such as deferred payment interest clauses, holder's relief clauses, etc. The main types of perpetual bonds issued in China are renewable corporate bonds, renewable directional financing instruments, renewable corporate bonds, perpetual securities and perpetual subordinated bonds. Since the issuance of China's first perpetual bond in 2013, the market has been booming. As of December 31,2017, a total of 774 perpetual bonds have been issued in China, with a total issuance scale of 1183.408 billion yuan, all of which are currently in the period of existence. The issuance scale from 2013 to 2017 were 3.30 billion yuan, 67.80 billion yuan, 387.40 billion yuan, 325.258 billion yuan and 399.650 billion yuan respectively [1]. In the case of unclear supervision, there are two major problems in the issuers and investors. One is how to confirm the perpetual bond in accounting, and the other is how to deal with the perpetual bond in taxation.

\section{Literature Review}

Despite the development of innovative tools in the financial market, the relevant government departments are not well-regulated in the supervision of mixed financing instruments. At present, the theoretical research results mainly focus on the properties of perpetual bonds and accounting problems, financial effects and taxation effects.

\subsection{Research on Perpetual Bonds Attributes and Accounting Treatment}

Based on the essential difference between equity and liability, China's accounting standards and the classification criteria of financial liabilities and equity instruments by international rating agencies, Wu Hui [2] analyzed that Hua Neng Perpetual Bonds should be recognized as a liability rather than as an equity. According to the regulatory agencies in China, Zhang Rigang [3] believes that the subordinated bonds, preferred stocks and perpetual bonds issued by financial institutions can be included in the company's subsidiary capital to enhance capital adequacy ratio and solvency. Therefore, from the issuer's subjective substantive point of view and in combination with relevant provisions of the contract, it can basically determine that the perpetual bonds capital attribute is higher, and it is a disguised equity 
refinancing method, which can be regarded as an equity instrument. Luo Qin [4] believes that rating agencies should confirm the strength of their stocks and bonds, and the issuer will split and list the perpetual bonds according to the result of rating confirmation. Zhang Yingwei and Hu Kun [5] pointed out that the economic essence of financial instruments should be reflected by combining the income distribution characteristics and perpetual characteristics of financial instruments. Chen Yao [6] believes that in distinguishing the attributes of perpetual bonds with both debt and equity characteristics, more attention should be paid to the economic substance reflected in the terms of its distribution. Punitive provisions are not currently considered to be definitive, but financial instruments that include such terms may be classified as financial liabilities in the future.

\subsection{The Impact of Perpetual Bonds Financing on Finance}

Shang Guanming, Zhou Wei, Bai Mengmeng [7] took Evergrande Real Estate's 2013 annual report as an example to analyze the impact the issuance of perpetual bonds on the changes of major financial data in the financial statements, from the perspective of solvency and operational capacity, profitability and other aspects of the impact of its main financial ratio. This paper analyzes the specific impact of perpetual bonds on corporate financial statements from four aspects: corporate capital expansion, cash flow improvement, capital utilization efficiency and financial risk. Zong Wenjuan, Zhang Quansheng, and Liu Di [8], through the comparative analysis of the financial effects of perpetual bonds, ordinary bonds and equity financing, they believed that enterprises issuing perpetual bonds have obvious advantages in terms of cost, risk and income. Earnings per share are significantly higher than those of unissued perpetual bonds. Gao Qian [9] found that issuing perpetual debt financing has advantages over equity financing and bond financing in terms of capital cost, risk and return, and that companies that issue perpetual bonds have higher earnings per share than those that are not issued. Lai Mengchao [10] compared the differences between Gemdale Group's perpetual debt financing, debt financing and equity financing from the perspectives of capital cost, risk and income. The research results are consistent with Gao Qian [9].

\subsection{The Impact of Perpetual Bonds on Corporate Taxation}

The tax issues related to perpetual bonds are mainly based on the Announcement on Tax-related Issues of Mixed Investment Business of Enterprises [2013(41)]. From the perspective of issuers, Ren Ming and Zhang Xin [11] believed that if the interest expense is included in the perpetual bonds, it is allowed to be deducted before tax. If the interest expense is included in the equity, it is not be deducted before tax. From the perspective of investors, it is considered that the business tax and corporate income tax for the perpetual bonds included in liabilities is reasonable and compliant, but the business tax and corporate income tax for the perpetual bonds included in equity is double taxation. Lai Meng chao [9] pointed out in his in-depth analysis of the first issue of perpetual bond of Jindi Group that because it does not conform to the "Announcement on Tax-related Issues of Mixed Investment Business of Enterprises", the interest on sustainable debt can not be paid in advance of tax, and it does not play the role of tax shield.

To sum up, based on the nature of liabilities and equity, and according to the standards of international rating agencies, the author believes that Chinese enterprises' perpetual bonds are of weak equity and strong debt, and it is advisable to include them in liabilities.

\section{Discussion on the Taxation of Perpetual Bonds}

\subsection{Issues Related to the Issuer's Income Tax}

\subsubsection{Issuer Recognized as Liability}

In 2016, X Group Co., Ltd. issued a period of 3+N, with an issue rate of $3.69 \%+2.3 \%=5.99 \%$ of the $\mathrm{RMB} 1.5$ billion medium-term notes. The fourth interest-bearing year begins to adjust the coupon rate once a year. Current coupon rate $=$ current benchmark interest rate + initial spread + reset times $*$ 300 basis points, interest rate jumps on each coupon reset date. During the audit, the author found that the company had a debt ratio of up to $80 \%$, and the parent company still recognized the permanent debt as a liability and included it in the debt payable-permanent debt. The reason is that the company has a large number of "other receivables", most of which are loans to subsidiaries of the parent company. When the SASAC evaluates the parent company, the corresponding part will be removed, so there is no assessment pressure. The holding intention of the parent company is very clear. That is annual interest payment and redemption at maturity. According to the requirements of economic substance over legal form, the parent company recognizes the bond as a liability, and the interest expense is included in the financial expense and deducted before tax. The annual interest expense is 89.85 million yuan $(150000 * 5.99 \%)$, which can save the income tax expenditure of 22.4625 million yuan, equivalent to 1.27 times of the company's 2017 profit, which has a very direct and significant impact on the parent company's profit and cash flow. It is understood that the expiration of the perpetual bond is basically subject to the repurchase right, which constitutes a "contractual obligation to exchange financial assets or financial liabilities with other parties under potentially adverse conditions" and does not meet the conditions for recognition of equity instruments.

\subsubsection{Issuer Recognized as Equity}

According to the Announcement on the Treatment of Enterprise Income Tax on Mixed Investment Business of Enterprises (2013[41]), the interest expense of perpetual bonds included in the equity is generally not allowed to be deducted before tax. The benefit of including perpetual bonds in equity is to optimize financial statements, reduce asset-liability ratios, and improve financing capabilities. 


\subsection{Issues Related to Investor Income Tax}

According to the Division of Financial Liabilities and Equity Instruments and Related Accounting Treatment Regulations [2014] No.13, when considering whether the financial instrument or its component parts are equity instruments or debt instruments, the investor (holder) of a financial instrument should follow the financial instrument recognition, measurement criteria and relevant requirements of these provisions, and should generally be consistent with the classification of the equity or liability attributes of the financial instrument by the issuer. For example, for non-derivative financial instruments classified by issuers as equity instruments, investors should usually classify them as equity instruments investments.

\subsubsection{Issuer Recognized as Liability}

When the issuer recognizes the perpetual bond as a liability, the investor should classify it as a debt instrument investment. The issuer deducts the interest expense before tax, so the interest income obtained by the investor has not been taxed accordingly. Therefore, the investor should levy a corresponding enterprise income tax in accordance with the Enterprise Income Tax Law of the People's Republic of China.

\subsubsection{Issuer Recognized as Equity}

When the issuer recognizes the perpetual bond as equity, the investor should classify it as an equity instrument investment. When the issuer recognizes the perpetual bond as an interest, the interest expense should not be deducted before tax, but as part of the after-tax profit distribution, so the investment income obtained by the investor has already been taxed once. This section levies taxes on investors once again, and there must be a problem of double taxation.

\subsection{Issues Related to Turnover Tax}

\subsubsection{Issuer}

Measures for Implementing the Pilot Program of Replacing
Business Tax with Value-Added Tax (Fiscal and Taxation (No. 2016) No. 36): General taxpayer of original value tax purchases passenger transportation services, loan services, catering services, residents' daily services and entertainment services, and the input tax amount should not be deducted from the output tax. Loan interest can only be issued with "VAT ordinary invoice", and "VAT special invoice" cannot be issued. The taxpayer accepts the loan service to the lender and the investment and financing consultant fees, handling fees, consulting fees and other expenses directly related to the loan, and the input tax amount should not be deducted from the output tax. In conclusion, as the general taxpayer of the issuer, the input tax of interest expenditure and financing related expenses should not be deducted.

\subsubsection{Investor}

According to Measures for Implementing the Pilot Program of Replacing Business Tax with Value-Added Tax (Fiscal and Taxation (No. 2016) No. 36) Provisions of Annex II:

(1) Loan service: the sales amount should be the total interest and interest income derived from the provision of loan services.

(2) Directly-charged financial services: the sales amount should be the service fees, commissions, remuneration, management fees, service fees, handling fees, account opening fees, transfer fees, settlement fees, transfer fees and other fees charged for providing direct fee financial services.

(3) The investor should pay VAT at the rate of $6 \%$ of "financial services", regardless of whether special invoices can be issued for the interest income or investment income of perpetual bonds.

\section{Conclusion and Outlook}

According to the above analysis, the income tax and VAT issues of investors and issuers in the perpetual bonds are summarized in Table 1.

Table 1. Summary of tax issues for investors and issuers of perpetual bonds

\begin{tabular}{llll}
\hline Project & Income tax & Turnover tax \\
\hline \multirow{2}{*}{ Recognize as liability } & Issuer & Interest expense is deductible before tax & Input tax is not eductible \\
& Investor & Pay corporate income tax & VAT payment \\
& Issuer & Interest expense is not deductible before tax & Input tax is not eductible \\
Recognized as equity & Investor & $\begin{array}{l}\text { Duplicate } \\
\text { taxation }\end{array}$ & VAT ayment \\
\hline
\end{tabular}

To sum up, according to the economic essence of the perpetual bond, the issuer should judge and should be recognized as a liability, or equity, or split between debt and equity. Investors should generally be consistent with the issuer's classification of the equity or liability attributes of financial instruments. In practice, the perpetual bond stock is weak and the debt is strong. The author believes that it is not appropriate to be accounted for as equity.

From the perspective of income tax, the issuer is recognized as a liability in accounting, and the corresponding interest expense can be deducted before tax. If it is recognized as equity, the interest expense cannot be deducted before tax. This conclusion has been basically recognized by the academic circle. From the perspective of tax planning, the tax-saving effect of perpetual bonds recognized as liabilities is considerable. However, the income of the investor is double-taxed. In order to eliminate the problem of double taxation, this paper proposes that the investor's perpetual bonds income should be treated as tax-exempt income. From the perspective of turnover tax, according to the current whether or not it can issue special VAT invoices, the investors should pay VAT. However, the issue fees and underwriting 
income of the issuer's interest expenses and financing are not deductible.

The issue of perpetual bond tax burden is not the only choice for enterprises to arrange business activities and financial activities, or even an important issue. Enterprises should make reasonable arrangements from the perspective of overall economic interests. With the development of China's economy, the demand for perpetual bond issuance is growing, and relevant departments should further standardize and clarify the taxation issues related to income tax and turnover tax. At the same time, it is necessary to strengthen the system of issuance conditions, credit rating, information disclosure, etc., in order to promote the rapid development of China's perpetual bond.

\section{References}

[1] Wang Yongle. Securities Rating Department of Pengyuan Credit Rating Co., Ltd.

[2] Wu Hui. Discussion on the Problem of Perpetual Debt Attribute of Chinese Enterprises [J]. Finance and Accounting. 2017 (13): $28-30$

[3] Zhang Rigang. Accounting Treatment of Innovative Financial Instruments in Financial Markets [J]. Finance and Accounting. 2016 (06): 45-46

[4] Luo Qin. Discussion on the Confirmation of Perpetual Equity Tool [J]. Communication of finance and accounting. 2017 (13): 74-77

[5] Zhang Yingwei, $\mathrm{Hu}$ Kun. Research on Accounting Confirmation of Innovative Financial Instruments with Dual Attributes [J]. Public Finance Research. 2015 (7): 88-93

[6] Chen Yao. Case study on the classification of perpetual debt accounting attributes [D]. East China Jiaotong University 2017 master degree thesis.

[7] Shangguan Ming, Zhou Wei, Bai Meng meng. Analysis of Evergrande Real Estate Financial Report Based on the Perspective of Perpetual Bonds-Taking Evergrande Real Estate 2013 Annual Report as an Example [J]. Finance and Accounting Monthly: 2015 (04): 74-76

[8] Zong Wenjuan, Zhang Quansheng, Liu Di. Research on Financial Effect of Perpetual Debt Financing__ Based on Financial Data of Listed Companies [J]. Communication of finance and accounting. 2017 (20): 45-47

[9] Gao Qian. Sustainable debt financing financial effect comparison [D]. Hangzhou University of Electronic Science and Technology 2015 master degree thesis.

[10] Lai Mengchao. Discussion on the treatment of perpetual debt taxation [J]. Communication of finance and accounting. 2018 (22): 73-77

[11] Ren Ming, Zhang Wei. The Impact of Perpetual Debt on Corporate Finance and Taxation [J]. Finance and Accounting. 2016 (22): 46-47

[12] Qiu Qiong et al. Will the use of derivative financial instruments increase corporate financial risk? [J]. Shanghai Finance. 2016 (8): 43-50

[13] Wang Zhiren.Study on financing preference and economic consequences of perpetual debt issuers [D]. Donghua University 2017 Master degree Thesis.

[14] Pei yue. Research on the division of financial liabilities and equity instruments [D]. Dongbei University of Finance and Economics 2016 master degree thesis.

[15] Wang Nan. Research on the Confirmation of Perpetual Debt Accounting in China Based on the Analysis of Financial Liabilities and Equity Tools [D]. Zhejiang Gongshang University. 2017 Master degree Thesis. 